\title{
Hubungan aspek klinis dan laboratorik dengan tipe sindrom nefrotik pada anak
}

\author{
${ }^{1}$ Robin S. Mamesah \\ ${ }^{2}$ Adrian Umboh \\ ${ }^{2}$ Stevanus Gunawan
}

\author{
${ }^{1}$ Kandidat Skripsi Fakultas Kedokteran Universitas Sam Ratulangi Manado \\ ${ }^{2}$ Bagian Ilmu Kesehatan Anak Fakultas Kedokteran Universitas Sam Ratulangi Manado \\ Email: robinsamuell12254@gmail.com
}

\begin{abstract}
Nephrotic Syndrome (NS) is one of the most frequent glomerular diseases in children marked with proteinuria, hypoalbuminaemia, and edema with or without hypercholesterolemia. Approximately there are six cases of NS per year every 100.000 child aged less than 14 years old in Indonesia with ratio between males and females 2:1. Based on therapy, NS is categorized into Steroid Sensitive Nephrotic Syndrome (SSNS) and Steroid Resistant Nephrotic Syndrome (SRNS). This study aimed to obtain the relationship between clinical and laboratory aspects with NS type in children. This was a retrospective analytical study conducted by using SSNS and SRNS patient data of the medical record in Department of Pediatric Prof. Dr. R. D. Kandou Hospital Manado. Daya were categorized into identity, age, blood pressure, proteinuria, hematuria, as well as albumin and cholesterol levels. The results showed that there were 29 SN patients (18 patients of SSNS and 11 patients of SRNS) consisted of 17 males (59\%) and 12 females (41\%). The statistical analysis showed that there was no significant correlation among sex $(\mathrm{p}=0.064)$, age $(\mathrm{p}=0.064)$, edema $(\mathrm{p}=0.138)$, systolic pressure $(0.283)$, diastolic pressure $(\mathrm{p}=0.701)$, proteinuria $(\mathrm{p}=0.999)$, hematuria $(\mathrm{p}=0.060)$, albumin $(\mathrm{p}=0.175)$, and cholesterol $(\mathrm{p}=0.814)$ in both of SSNS and SRNS patients. Conclusion: There was no relationship between sex, age, blood pressure, proteinuria, hematuria, albumin, and cholesterol related to SSNS and SRNS.
\end{abstract}

Keywords: nephrotic syndrome, proteinuria, SSNS, SRNS

\begin{abstract}
Abstrak: Sindrom nefrotik (SN) adalah salah satu penyakit glomerulus yang sering ditemukan pada anak, yang ditandai dengan proteinuria, hipoalbuminemia, dan edema dengan atau tanpa hiperkolesterolemia. Diperkirakan enam kasus per tahun tiap 100.000 anak kurang dari 14 tahun di Indonesia dengan perbandingan antara laki-laki dan perempuan 2:1. Sindrom nefrotik berdasarkan respon terapinya terbagi menjadi sindrom nefrotik sensitif steroid (SNSS) dan sindrom nefrotik resisten steroid (SNRS). Penelitian ini bertujuan untuk mengetahui hubungan aspek klinis dan laboratorium dengan tipe SN pada anak. Jenis penelitian ini analitik retrospektif pada pasien SNSS dan SNRS berdasarkan data rekam medik di Bagian Ilmu Kesehatan Anak RSUP Prof. Dr. R. D. Kandou Manado. Data dikumpulkan meliputi identitas, usia, tekanan darah, proteinuria, edema, hematuria, hematuria, serta kadar albumin dan kolesterol. Hasil penelitian memperlihatkan 29 pasien SN terdiri dari 18 pasien SNSS dan 11 pasien SNRS. Laki-laki sebanyak 17 kasus (59\%) dan perempuan 12 kasus (41\%). Tidak didapatkan hubungan pada jenis kelamin $(\mathrm{p}=0,064)$, usia $(\mathrm{p}=0,064)$, edema $(\mathrm{p}=0,138)$, tekanan darah sistolik $(\mathrm{p}=0,283)$, tekanan darah diastolik $(\mathrm{p}=0,701)$, proteinuria $(\mathrm{p}=0,999)$, hematuria $(\mathrm{p}=0,060)$, albumin $(\mathrm{p}=0,175)$, kolesterol $(\mathrm{p}=0,814)$ pada kedua kelompok. Simpulan: Tidak terdapat hubungan antara jenis kelamin, usia, tekanan darah, proteinuria, hematuria albumin dan kolesterol dengan SNSS dan SNRS.
\end{abstract}

Kata kunci: sindrom nefrotik, proteinuria, SNSS, SNRS.

Sindrom nefrotik (SN) adalah salah satu penyakit glomerulus yang sering ditemukan pada anak, yang ditandai dengan proteinuria ( $\left.>40 \mathrm{mg} / \mathrm{m}^{2} / \mathrm{jam}\right)$, hipoalbumin 
$(<2,5 \mathrm{~g} / \mathrm{dL}), \quad$ hiperkolestronemia $\quad(>250$ $\mathrm{mg} / \mathrm{dL})$, dan edema. ${ }^{1,2}$ Insiden penyakit SN primer dua kasus per tahun tiap 100.000 anak berumur kurang dari 16 tahun. Insiden di Indonesia diperkirakan enam kasus per tahun tiap 100.000 anak kurang dari 14 tahun. Sindrom nefrotik lebih banyak diderita oleh anak laki-laki daripada anak perempuan dengan perbandingan $2: 1{ }^{3}$ Diagnosis SN ditegakkan berdasarkan gejala klinis yang seringkali ditandai dengan edema yang timbul pertamakali pada daerah sekitar mata dan ekstremitas bagian bawah. Tekanan darah meningkat pada $25 \%$ anak, diare akibat edema intestinal dan distres pernafasan akibat edema pulmonal atau efusi pleura dapat di temukan. Pada kasus tertentu dapat disertai hipertensi dan hematuria. ${ }^{2,4}$

Berdasarkan respon terapinya, sindrom nefrotik terbagi menjadi sindrom nefrotik sensitif steroid (SNSS) dan sindrom nefrotik resisten steroid (SNRS). Jumlah pasien SNRS pada anak memiliki persentasi yang lebih kecil (20\%) dibandingkan dengan SNSS, tetapi SNRS masih merupakan masalah bagi dokter nefrologi anak karena kronisitas, sulitnya penanganan dengan obat-obatan, serta kemungkinan menjadi penyakit ginjal kronik. ${ }^{3,5,6}$

Sindrom nefrotik primer atau idiopatik sering terlihat 95\% dari pasien, $80 \%$ di antaranya menunjukkan SNKM dan memiliki prognosis baik. Meskipun kekambuhan adalah sifat umum SN, 9095\% anak dengan SNKM responsif terhadap terapi steroid dengan menyelesaikan klinis remisi biokimia dan memiliki prognosis jangka panjang yang sangat baik. ${ }^{7}$ Sindrom nefrotik pada anak yang didiagnosis secara histopatologik sebagai lesi minimal, sebagian besar akan memberikan respons terhadap pengobatan steroid. Pada SN lesi nonminimal sebagian besar tidak memberikan respons terhadap pengobatan steroid. Sampai saat ini, belum terdapat data gambaran histopatologik di Indonesia, sehingga pada SNRS dan SNSS akan memberikan gambaran klinis yang berbeda dengan penelitian yang dilakukan oleh International Study of Kidney diseases in Children (ISKDC). ${ }^{8}$

Penelitian ini bertujuan untuk mengetahui hubungan aspek klinis dan laboratorium dengan tipe sindrom nefrotik pada anak.

\section{METODE PENELITIAN}

Jenis penelitian ini ialah analitik retrospektif, dan dilakukan di Bagian Ilmu Kesehatan Anak RSUP Prof. DR.R.D.Kandou Manado. Data diambil dari rekam medis pasien sindrom nefrotik selama periode 2010-2014. Subjek penelitian ialah semua pasien dengan diagnosis SNSS dan SNRS. Kriteria inklusi ialah anak usia 1-14 tahun dan memiliki catatan medis lengkap. kriteria eksklusi penderita gagal ginjal akut atau kronik, penyakit kronik lainnya seperti hipertensi kronis, tuberkulosis, keganasan, dan malnutrisi berat. Data yang dikumpulkan meliputi identitas, usia, tekanan darah, proteinuria, hematuria, hematuria, albumin dan kolesterol. Data diolah dengan program IBM SPSS statistik 22. Hubungan masingmasing faktor tersebut dengan respons terhadap pengobatan steroid dianalisis secara univariat menggunakan uji chisquare, dan untuk menguji hubungan berbagai variabel digunakan analisis regresi logistik sederhana.

\section{HASIL PENELITIAN}

Berdasarkan penelitian yang dilakukan di RSUP Prof. Dr. R. D. Kandou Manado diperoleh total sampel sebanyak 29 pasien dengan jumlah pasien SNSS sebanyak 18 orang dan SNRS sebanyak 11 orang yang memenuhi kriteria inklusi. Tabel 1 memperlihatkan distribusi jenis kelamin pasien berdasarkan diagnosis. Pada distribusi pasien edema berdasarkan diagnosis diperoleh pasien nonedema sebanyak 1 orang (3\%), edema lokal 15 orang (52\%), dan edema anasarka 13 orang (45\%) (Tabel 2).

Tabel 3 memperlihatkan analisis variabel pada sindrom nefrotik sensitif steroid dan resisten steroid. Tabel ini memperlihatkan rerata, simpang baku, dan 
rentang pada varibel usia, tekanan darah sistolik, tekanan darah diastolik, proteinuria, hematuria, kadar albumin dan kadar kolesterol pada sindrom nefrotik sensitif steroid dan sindrom nefrotik resisten steroid.

Tabel 1. Distribusi jenis kelamin pasien berdasarkan diagnosis

\begin{tabular}{lccc}
\hline \multirow{2}{*}{ Jenis kelamin } & \multicolumn{2}{c}{ Diagnosis } & \multirow{2}{*}{ Jumlah (\%) } \\
\cline { 2 - 3 } & SNSS (\%) & SNRS (\%) & $17(59)$ \\
Laki-laki & $13(72)$ & $4(36)$ & $12(41)$ \\
Perempuan & $5(28)$ & $7(64)$ & $29(100)$ \\
Total & $18(100)$ & $11(100)$ & \\
\hline
\end{tabular}

Tabel 2. Distribusi pasien edema berdasarkan diagnosis

\begin{tabular}{lccc}
\hline \multirow{2}{*}{ Edema } & \multicolumn{2}{c}{ Diagnosis } & \multirow{2}{*}{ Jumlah (\%) } \\
\cline { 2 - 3 } & SNSS (\%) & SNRS (\%) & $1(3)$ \\
Non-edema & $1(6)$ & $0(0)$ & $15(52)$ \\
Edema lokal & $11(61)$ & $4(36)$ & $13(45)$ \\
Edema Anasarka & $6(33)$ & $7(64)$ & $29(100)$ \\
Total & $18(100)$ & $11(100)$ & \\
\hline
\end{tabular}

Tabel 3. Analisis variabel pada sindrom nefrotik sensitif steroid dan resisten steroid

\begin{tabular}{lll}
\hline \multirow{2}{*}{ Variabel } & \multicolumn{2}{c}{ Kelompok } \\
\cline { 2 - 3 } & \multicolumn{1}{c}{ SNSS } & \multicolumn{1}{c}{ SNRS } \\
\hline Usia, (rerata (SB); rentang) & $6,89(3,234) ; 2-13$ & $6,91(2,508) ; 2-11$ \\
TDS (rerata (SB); rentang) & $111,67(9,852) ; 90-130$ & $118,18(22,279) ; 90-160$ \\
TDD (rerata (SB); rentang) & $74,44(11,991) ; 60-100$ & $76,36(15,667) ; 60-100$ \\
Proteinuria (rerata (SB); rentang) & $288,89(220,831) ; 25-500$ & $500(-) 500$ \\
Hematuria (rerata (SB); rentang) & $82,50(97,758) ; 10-250$ & $164,09(119,265) ; 10-250$ \\
Albumin (rerata (SB); rentang) & $2,555(1,624) ; 1.10-7.10$ & $1,770(0,862) ; 0.90-3.70$ \\
Kolesterol (rerata (SB); rentang) & $379,50(167,837) ; 106-817$ & $395,27(201,564) ; 200-797$ \\
\hline
\end{tabular}

Tabel 4. Analisis bivariat berbagai variabel dengan SNSS dan SNRS

\begin{tabular}{lcc}
\hline \multicolumn{1}{c}{ Variabel } & $\begin{array}{c}\text { Koefisien } \\
\text { regresi }\end{array}$ & Nilai p \\
\hline Jenis Kelamin & 1,515 & 0,064 \\
Usia & 0,002 & 0,985 \\
Edema & 1,110 & 0,138 \\
Tekanan darah sistolik & 0,028 & 0,283 \\
Tekanan darah diastolik & 0,011 & 0,701 \\
Proteinuria & 0,057 & 0,999 \\
Hematuria & 0,007 & 0,060 \\
Albumin & $-0,567$ & 0,175 \\
Kolesterol & 0,001 & 0,814 \\
\hline *diuji dengan analisis regresi logistik sederhana.
\end{tabular}

Hubungan antara variabel tersebut terlihat dengan kejadian SNSS ataupun SNRS, tetapi setelah diuji secara statistik dengan analisis regresi logistik sederhana ternyata tidak ada variabel yang memperlihatkan hasil bermakna (Tabel 4). Untuk variabel jenis kelamin didapatkan nilai $\mathrm{p}=0,064$, usia 0,064 , edema $\mathrm{p}=0,138$, tekanan darah sistolik 0,283, tekanan darah diastolik $\mathrm{p}=0,701$, proteinuria $\mathrm{p}=0,999$, hematuria $\mathrm{p}=0,060$, albumin $\mathrm{p}=0,175$, dan kolesterol $\mathrm{p}=0,814$.

\section{BAHASAN}

Sindrom nefrotik lebih banyak diderita oleh anak laki-laki daripada anak perempuan dengan perbandingan $2: 1{ }^{3}$ Penelitian yang dilakukan di RSUP Dr. Kariadi Semarang dengan distribusi jenis kelamin SN primer terdiri atas laki-laki $74,4 \%$ dan perempuan $25,6 \%$ dengan rasio 
2,9:1. ${ }^{9}$ Berdasarkan hasil yang diperoleh pasien berjenis kelamin laki-laki sebanyak 17 orang (59\%) dibandingkan dengan jenis kelamin perempuan sebanyak 12 orang (41\%), namun pada SNRS menunjukan perbedaan jenis kelamin yaitu pasien SNRS berjenis kelamin perempuan sebanyak 7 orang (64\%) dibandingkan dengan jenis kelamin laki-laki yaitu sebanyak 4 (36\%). Penelitian yang dilakukan oleh Wisata et al. ${ }^{8}$ didapatkan bahwa jenis kelamin perempuan memiliki risiko untuk menjadi resisten steroid sebesar 4,82 kali dibandingkan dengan laki-laki. Hal ini serupa dengan penelitian yang dilakukan ISKDC, namun belum ada penjelasan yang mendalam mengenai karakteristik jenis kelamin ini.

Keluhan utama seorang anak yang menderita SN ialah edema. Edema timbul karena terdapat akumulasi cairan ekstrasel pada jaringan interstitial. ${ }^{10}$ Kelsch et al. ${ }^{10}$ mengemukakan bahwa anak penderita sindrom nefrotik dalam serangan, edema mulai timbul bila kadar albumin $<2,7 \mathrm{~g} / \mathrm{dL}$ dan selalu ditemukan apabila kadar albumin $<1,8 \mathrm{~g} / \mathrm{dL}$. Pada penelitian ini diperoleh pasien edema sebanyak 18 orang pada SNSS dan 11 orang pada SNRS, namun didapatkan satu pasien non-edema pada SNSS dengan kadar albumin7,1 g/dL. Sesuai penjelasan yang dikemukakan oleh Kelsch et al. ${ }^{10}$ sebelumnya yang menerangkan mengapa kejadian non-edema terjadi pada pasien tersebut. Nilai albumin pada kedua kelompok penelitian ini menunjukan tidak ada hubungan bermakna. Penurunan kadar albumin pada pasien SN terjadi akibat peningkatan filtrasi glomerulus terhadap albumin sehingga terjadi proteinuria masif dan kadar albumin serum menurun, meskipun sintesis albumin di hepar meningkat sampai 3-4 kali. Sintesis yang meningkat ini tidak cukup untuk mengompensasi kehilangan albumin. $^{11}$

Hasil penelitian ini menunjukkan bahwa proteinuria pada SNSS dan SNRS dengan nilai $500 \mathrm{mg} / \mathrm{dl}$ diperoleh sebanyak 20 orang dengan rerata pada SNSS 288.89 $\mathrm{mg} / \mathrm{dl}$ dan rerata pada SNRS $500 \mathrm{mg} / \mathrm{dl}$. Hasil penelitian ini sesuai dengan penelitian yang didapatkan oleh Handayani $^{9}$ di RS Dr. Wahidin Sudirohusodo Makassar, yaitu kadar protein urin semikuantitatif pada sindrom nefrotik terbanyak ialah +3 (300-1000 $\mathrm{mg} / \mathrm{dl})$. Hasil penelitian ini tidak mendapatkan hubungan bermakna proteinuria pada kejadian SNSS dan SNRS.

Penelitian yang dilakukan oleh Wisata et al. ${ }^{8}$ di Rumah Sakit Dr. Hasan Sadikin Bandung pada tahun 2010 terhadap 76 anak diperoleh hasil yang sama dimana kejadian hipertensi dan hematuria tidak berhubungan dengan SNRS dan SNSS. Pada penelitian ini juga didapatkan kejadian hipertensi dan hematuria tidak berhubungan dengan SNRS dan SNSS.

Keterbatasan penelitian ini ialah tidak adanya data mengenai gambaran histopatologik pada kedua kelompok, karena tidak dilakukan biopsi. Selain itu pencapaian nilai kemaknaan memerlukan jumlah yang lebih besar sedangkan pada penelitian ini hanya mendapatkan 29 sampel.

Kolesterol pada penelitian ini memiliki nilai rerata $379,50 \mathrm{mg} / \mathrm{dl}$ pada SNSS dan $395,27 \mathrm{mg} / \mathrm{dl}$ pada SNRS. Nilai kadar kolesterol rerata pada SNRS sedikit lebih tinggi dibandingkan dengan nilai kadar kolesterol rerata pada SNSS. Penelitian yang dilakukan oleh Dnjanesh et al. ${ }^{12}$ di Pediatric Wards of Fr. Muller Medical College Hospital memperoleh hasil yang sama dimana kadar kolesterol rerata pada SNRS lebih tinggi dibandingkan kadar kolesterol rerata SNSS. Milne ${ }^{12}$ melaporkan kadar kolesterol total pada SN mungkin dapat meningkat hingga $1000 \mathrm{mg} / \mathrm{dl}$. Dalam penelitian ini nilai kadar kolesterol tertinggi pada SNSS 817 mg/dl dan pada SNRS 797 mg/dl. Kadar kolesterol total juga tidak menunjukan hubungan bermakna. Menurunnya kadar albumin plasma akan menstimulasi sintesis lipoprotein oleh hepar. Menurunnya klirens lemak dalam darah akibat berkurangnya enzim lipase sebagai katalisator lemak yang ikut bocor bila terjadi kelainan pada tubuli, juga menerangkan terjadinya hiperkolesterolemia pada penderita sindrom nefrotik. ${ }^{3,8}$ 


\section{SIMPULAN}

Berdasarkan hasil penelitian pada anak dengan sindrom nefrotik di RSUP Prof. Dr. R.D Kandou Manado periode 2010 sampai 2014 dapat disimpulkan tidak terdapat hubungan bermakna antara beberapa aspek klinis dan laboratorium yaitu usia, edema, hipertensi, proteinuria, hematuria, albumin dan kolesterol dengan respon pengobatan sindrom nefrotik sensitif steroid dan sindrom nefrotik resisten steroid.

\section{DAFTAR PUSTAKA}

1. Bhimma R. Steroid sensitive nephrotic syndrome in children. J Nephrol Therapeutic. 2014;4(11):1-10.

2. Davis ID, Avner ED. Nephrotic syndrome. In: Behrman RE, Kliegman RM, Jenson HB, penyunting. Nelson Textbook of Pediatrics (17th ed). India: Saunders Elsevier, 2006; p.1753-7.

3. Wirya IW. Sindrom nefrotik. In: Alatas H, Tambunan T, Trihino PP, Pardede SO, penyunting. Buku Ajar Nefrologi Anak (2nd ed). Jakarta: FKUI, 2009; p. 381-421.

4. Nilawati GAP. Profil sindrom nefrotik pada ruang perawatan anak RSUP Sanglah Denpasar. Sari Pediatri. 2012;14:26971.

5. Wilson LM. Gagal ginjal kronik. In: Hartanto H, Susi N, Wulansari P, Mahanani DA, penyunting. Patofisiologi-konsep klinis prosesproses penyakit (6th ed). Jakarta:
EGC, 2005; p. 912-49.

6. Purnawati E, Hilmanto D, Suardi A. Hubungan kadar albumin serum dengan eritropoetin serum pada sindrom nefrotik anak resisten steroid. Sari Pediatri. 2015;16:31517.

7. Roy $\mathbf{R}$, Islam $\mathbf{R}$, Matin $A$, Khan $\mathbf{R}$, Muinuddi G, Rahman $H$, et al. Relationship of childhood idiopathic nephrotic syndrome with asthma, hypertension, complement c3, urinalysis. Bangladesh Child Health. 2011;35:11-5.

8. Wisata L, Presetyo D, Hilmanto D. Perbedaan aspek klinis sindrom nefrotik resisten steroid dan sensitive steroid pada anak. MKI. 2010;60:559-63.

9. Kasma K, Marlinah. Karakteristik penderita sindrom nefrotik pada anak. Journal of Pediatric Nursing. 2014;99-103.

10.Novena, Gurnida D, Sekarwana N. Kolerasi kadar albumin serum dengan persentase edema pada anak penderita sindrom nefrotik dalam serangan. MKB. 2014;47:55-58

11.Garniasih D, Djais T, Garna H. Hubungan antara kadar albumin dan kalsium serum pada sindrom nefrotik anak. Sari Pediatri. 2008;10:100-104.

12.Dnyanesh D, Dnyanesh S, Shenoy V. A study of serum lipids in nephritic syndrome in children. IORS-JDMS. 2014;13:1-5. 